\title{
MERMAID ICONOGRAPHY AND EARLY MODERN ANGLO-AMERICAN MARITIME CULTURE
}

[Received June 27th 2020; accepted August 11th 2020 - DOI: 10.21463/shima.113]

\section{Vaughn Scribner}

\author{
University of Central Arkansas, Conway, USA <vscribner@uca.edu>
}

\begin{abstract}
This article builds upon recent research on early modern Anglo-American maritime culture to demonstrate how mariners used shared mermaid iconography (such as spaces, symbolism, objects, superstitions, and songs) to cultivate an imagined community' that linked their lives at sea to that on land, and vice versa. Ships and taverns were key to such efforts, as these public spheres - themselves branded by mermaid iconography - served as well-recognised nodes of maritime identity-ways. Ultimately, early modern Anglo-American sailors claimed mermaid iconography as critical symbols of maritime culture that transcended space and time, thereby helping diverse constituents of global empires to create connections wherever they travelled.
\end{abstract}

KEYWORDS: Sailors; Anglo-American; maritime culture; mermaid; iconography; tavern; ship

In April 1763, Jackson's Oxford Journal (UK) reported the marriage of a sailor and a servant woman in London. The mariner served on the warship, The Fortune of War, while the maid worked at the Mermaid Tavern in Great-Carter Lane (London) (Unattributed, 1763: 3). It is no stretch of the imagination to surmise that the sailor met his bride while downing pints at the Mermaid Tavern during a sojourn from sea (as one historian noted, "taverns and ships themselves became centres of social interaction and information exchange between mariners and [land-dwellers]") (Hatfield, 2004: 61). ${ }^{1}$ Only five years later, a far less joyous event involving mermaids and mariners occurred, when the Hartford Courant (Connecticut) recorded the "execution of the Sailor on board the Mermaid" (Unattributed, 1768: 3). A week earlier, he and two others were caught deserting their post. Though the head deserter's shipmates "were sentenced to be flogged from ship to ship," he ended up dangling from the mast of "his Majesty's ship Mermaid" (ibid).

In 1845 , finally, United States Navy sailors were furious when the owner of a steamboat's bar refused them entry while on a voyage from Amboy to New York. Aghast that the "aristocratic dram shop" had infringed upon "the ever-to-be-respected doctrine of Free Trade and Sailors Rights," the rowdy group burst into the floating tavern and downed most of its liquor without paying. One whale man took to the time-honoured nautical tradition of scrimshaw to mock his comrades' irritation (Figure 1). That the etched whale tooth featured an eagle, "Free Trade \& Sailor's Rights," and “Jack Contending for the Motto" made

\footnotetext{
${ }^{1}$ Benjamin Carp explained that mariners formed the Marine Society at a tavern in New York City in the 1760s (2007: 76).
}

Shima <www.shimajournal.org $>$ ISSN: 1834-6057 
perfect sense according to sailors' assertions of liberty and trade (Gilje, 2013: 324-5). Yet, the maritime artist depicted more than politics, as he also included a variety of other wellknown iconographies of early modern sailors on the scrimshaw tooth, including a bottle of grog, an anchor, and, of course, a mermaid, featured front-and-centre.

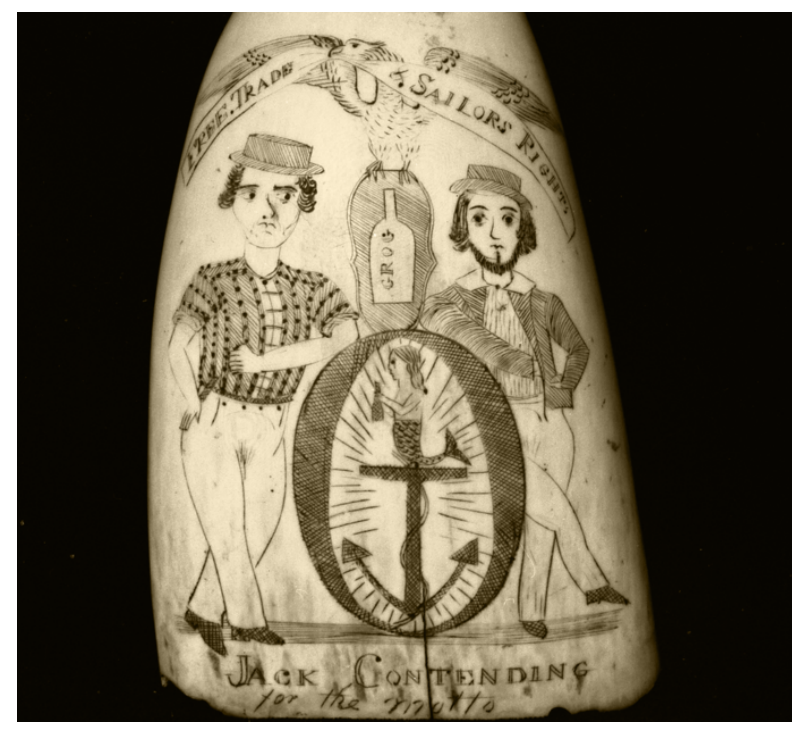

Figure 1 - 'Jack Contending for the Motto' (1845). (New Bedford Whaling Museum.)²

As illustrated by the above examples, early modern British and, eventually, American sailors' lives were inherently intertwined with mermaid symbolism. Various historians have analysed mariners' complex association with "a larger Anglo-American culture" (Gilje, 2016: 1; Linebaugh and Rediker, 200o; Bolster, 1997). This article builds upon such studies to demonstrate how itinerant Anglo-American mariners relied upon shared mermaid iconography (e.g. spaces, symbolism, objects, superstitions, and songs) to cultivate an "imagined community" of maritime culture which linked their lives at sea to that on land, and vice versa. ${ }^{3}$ Ships and taverns were imperative in such efforts, as these 'public spheres' - themselves branded by mermaid iconography - served as reliable nodes ("islands," if you will) of maritime identity-ways. ${ }^{4}$ Ultimately, sailors claimed mermaid iconography as key symbols of maritime culture which transcended space and time; "the often artificial barriers of regional-national history”(Rediker, 1987: 8). Such endeavours

\footnotetext{
${ }^{2}$ New Bedford Whaling Museum Catalogue \# 1959.8.10.

${ }^{3}$ I am loosely employing Benedict Anderson's definition of an imagined community, not in terms of nationalism but rather in his assertion that members of an "imagined community" feel this way despite (or because of) the fact that "the members of even the smallest [community] will never know most of their fellow-members, meet them, or even hear of them...yet in the minds of each lives the image of their communion" (2006: 6).

${ }^{4}$ I am also utilising Habermas' notion of the public sphere. In this case, I am especially interested in Gilje's assertion that historians have recently broadened Habermas' public sphere to include groups beyond the middle class. I will be following Gilje's approach to the early modern public sphere, which "discuss the interactions between the maritime and mainstream cultures through language, ideas, behavior, the printed word, images, and material goods that were connected to the public sphere" (Gilje, 2016: 3) - also see Gillis (2004).
} 
helped mariners to carve out their own culture within a world which often relegated them to the literal and figurative fringes of society.

Though often a nebulous idea among historians of early modern Anglo-American sailors, maritime culture is most generally associated with mariners' ever-evolving notions of liberty, masculinity, race, and sociability. Unsurprisingly, sailors' association with mermaid iconography succinctly reflected their ideals of maritime culture. Although for much of the 16th and 17th centuries sailors generally understood mermaids as dangerous sirens who might wreck their ship or portend misfortune, by the 18th Century they began to relate mermaids with notions of wonder, sex, and exploration. Much of this transformation can be chalked up to 18th Century Anglo-Americans' assertions of mastery over the natural world, as well as advances in science, technology, and trade (Scribner, 2017: 507-38). Ultimately, sailors' heightened acceptance of mermaids as harbingers of hope as much as doom made them key vessels of cultural formulation.

Arguments over liberty were paramount for sailors' sense of self and, in turn, their efforts at cultivating a shared maritime culture. As historian Paul Gilje argued, sailors utilised the "ambiguous and contested meanings" of liberty both on land and at sea, often for pragmatic, personal reasons (2004: xiv). On land, many mariners felt stripped of their liberty (even if they were actually freer on land than at sea), while they generally associated the sea with true liberty (even though they were technically trapped on a floating prison). As some of the oldest, most recognisable symbols of the mysteries and expanses of the ocean, mermaids were obvious representations of mariners' complicated lust for liberty. Just as sailors were willing to brave the dangers of the ocean in a quest for true freedom, so too were they ready to embrace the symbolism of mermaids - surfeit with sex, power, and adventure - even if it could mean their ultimate demise at the hands of these eerie sirens. The mermaid was a "dedely beast" that, in the words of the 16th Century author Andrew Laurence, would "bringeth a man gladly to dethe" (1527: 151). Yet, so might each mutable cultural cue - maritime liberty and mermaid iconography - offer sailors the freedom they so ardently sought.

The same went for masculinity. Whether on land or at sea, sailors strove to assert their manhood through drinking, gambling, sex, fighting, swearing, labour, and profit (among other things). At sea, common sailors were regularly emasculated by their superiors, not to mention the ravages of the natural world. On land, similarly, they often fell victim to creditors and legal issues, as they overspent at taverns and brothels, or broke the law (often in the same spaces). They were looked down upon many common citizens as the dregs of culture; "jolly, childlike, irresponsible" vagabonds who hopped from port to port leaving devastation in their wake (Lemisch, 1968: 380).

Although women occasionally boarded ships as captains' wives or whalers, their presence at sea was miniscule (Creighton and Norling, 1996: 70-117). Sailors accordingly spent much of their lives missing loved ones, particularly female loved ones (Gilje, 2004: 33-65). Often socially marginalised and longing for female companionship, mariners sought a common symbol which might bolster their shared need for masculine control while also demonstrating their Eros: mermaids, once again, fit the bill. Whether on the prow of a ship, the arm of a sailor, or the tip of a cane, mermaids allowed seamen to connect with each other according to early modern notions of manliness and power, especially in contrast to understandings of femininity and physical "weakness." As historians Margaret Creighton and Lisa Norling asserted, mariners liked to represent themselves as masculine icons, while 
relegating the feminine to an inferior position "as stiff and objectified as the wooden figureheads that faced the sea" (2006: vii).

Notions of race also figured prominently into sailors' conceptions of maritime culture. Though popular 2oth and 21st Century Western representations of maritime culture often depict sailors as white men, a considerable number of early modern Anglo-American sailors were African Americans. In fact, seafaring proved one of the most popular occupations for free and enslaved black men between 1740 and 1865 . The historian W. Jeffrey Bolster noted that black sailors were "actively contributing to the Atlantic maritime culture shared by all seamen." Bolster continued, "that [maritime] culture created an ambiguous world" where black men might at once "assert themselves within their occupation" and "transcend race, while also being subject to vicious racist attacks" (1997: 5) (also see Schoeppner, 2019).

Mermaid iconography reflected African Americans' dualistic nature in maritime culture, which African Americans helped to create yet "were at times outsiders within" (Bolster, 1997: 5). Though mermaids were common symbols of Anglo-American sailor culture (which was cultivated by white and black men), Euro-American mariners almost always depicted mermaids with porcelain white skin and European facial features. This ran counter to older traditions surrounding mermaids, as African and Afro-Caribbean peoples had long drawn, written about, and carved dark-skinned sirens and water spirits (Drewal, 2008). No matter black sailors' vast numbers and critical contributions to early modern maritime culture, African Americans were largely cut out of popular representations of that same culture.

Beyond complicated notions of liberty, masculinity, and race, mermaids' ubiquitous-yetmysterious nature also made them perfect figures for maritime sociability; namely regarding songs, stories ("yarns"), superstitions, and sightings. Mariners endured long, arduous hours at sea-songs encouraged community during work and play, while stories and sightings fostered deeper connections during down-time. On land (especially in taverns), mariners employed these same songs and stories to distinguish themselves and, in turn, cultivate closer connections among a broad populace (Gilje, 2016: 106-81). From ballads, to poems, tall tales, and unsolved mysteries, mermaids figured prominently in sailors' never-ending quest at upholding a maritime culture through mutual social cues.

Were mermaids real, or simply icons of early modern culture? Had sailors seen them, or were they just spinning more yarns? Why were there so many songs, stories, and sightings surrounding these mythical creatures, and why had they retained cultural relevance in the maritime community for so long? Early modern mariners were less concerned with answering these questions than they were with using mermaids - perhaps the most ubiquitous, mutable, and recognisable of all mythical sea creatures - to strengthen the bonds of maritime life. Mermaids, in short, provided the ideal binding symbol for men who lived on the fringes of the land; and society, for that matter.

Ships and taverns were the two most popular spaces for the transmission and reinforcement of maritime culture at sea and on land, respectively. Both spaces were predicated upon profit, communication, and, in a sense, liberty. Commercially, ships and taverns were "businesses...complex community developmental institutions" that early modern peoples used "to create and maintain the overlapping networks that made up their communities" (Brennan, Hancock, and McDonald, 2011: xii, xix). Whether a whaling, commercial, military, or pirate operation, ships had to make a profit to be viable, as did their crew. Sometimes this meant taking an especially dangerous passage, or perhaps 
attacking other ships. The same went for taverns. Their owners did everything in their power to bring in as many customers as possible: they offered cheap alcohol, a variety of social and commercial opportunities, and, of course, sex.

Like tavernkeepers, ship captains and officers had to project notions of sociability and liberty on board their vessels. Given, ships were some of the most hierarchical, confined spaces in the early-modern Anglo-American world, but this did not mean that common sailors entirely gave up on their freedom. In fact, they often attempted to extend those liberties they so enjoyed in port taverns to the sea, which sometimes caused tension between common sailors and their superiors. This "constant negotiation" among the ship's ranks only further extended notions of profit, sociability, and liberty from land to sea, and back again (Gilje, 2016: 83).

In an overt effort to link their businesses to maritime culture and its prime constituents, ship captains and tavernkeepers named their crafts and businesses after mermaids. Though such practices were not unique to the early modern period, the historical record is especially rife during the 18th and 19th centuries. One only has to scan Anglo-American newspapers to realise the ubiquity of ships named Mermaid or Siren. In 1758, London's Public Advertiser noted that "the good ship MERMAID, a prime Sailor, square Stern, NewEngland built" could be purchased at Lloyd's Coffee House (Public Advertiser, June 16, 1758). Ever abreast of the shipping lanes which were so imperative for their success, major cities' newspapers also regularly printed ship arrivals. In 1787, The London Times reported that the Mermaid had recently arrived from Antigua (London Times, August 6, 1787), while Philadelphia's Pennsylvania Gazette recorded in 1752 that the "Sloop Mermaid" had just been cleared to sail for Newfoundland (Pennsylvania Gazette, July 23, 1752).

Ships of war, finally, protected and extended the shipping networks which kept the British Empire afloat. Unsurprisingly, they also boasted mermaid titles. London's Public Advertiser narrated an exciting chase in which the British Navy ship, Mermaid, led a French sloop straight to its doom, as the French captain trailed, "calling out, $D-n$ you, strike, ye English Dogs, or I'll sink ye" (Unattributed, 1760: 2). Three years later, the Pennsylvania Gazette entertained readers with the tale of "Captain Hunter of the Mermaid" who almost caught five French men of war off the coast of the Orkney Islands (Unattributed, 1755: 2).

When it came to profit-seeking and mermaid branding, tavernkeepers were no different than their maritime counterparts. In fact, while ship captains generally named their vessels after mermaids because of a general recognition of sea culture and easy branding, publicans took greater, more specific, measures in naming their establishments, since they sought to attract a certain subset of customers - sailors - from the moment they leapt off the ship, rushed through winding streets loaded with other taverns, and (hopefully) arrived at their business. Interestingly, the most famous of all "mermaid taverns," that 17th Century Bread Street, London institution of wit, clubbing, and high-brow erudition, was the exception to the rule when it came to mermaid-branded taverns. Rather than elite customers like Ben Jonson who so loved the Mermaid, most Anglo-American mermaid taverns served lower-class patrons, especially sailors. Furthermore, their menus consisted of coarse meals - cuts of cheap meat, oysters, bread - rather than the formal dinners such as the expensive "loyn of porke" which the more famous Mermaid Tavern regularly served (O'Callaghan, 2004: 37-51). Finally, early modern parlance often associated the term "mermaid" with prostitutes. Taverns were centres for prostitution (officials often referred to such spaces as "bawdy" or "disorderly" houses) (Goodman 1983: 33). Thus, mermaid- 
branded taverns might have also hinted at sexual services within their walls, especially for sailors who had spent months at sea.

Owners of mermaid-branded taverns also often depicted a mermaid on their sign so that customers who could not read might still identify their drinking space as friendly to the maritime community. As H. Syer Cuming contended in 1881, "the mermaid was a very favourite sign with the old London traders" (Cuming, 1882: 63). From London to Barbados, one was always sure to find a mermaid sign hanging over at least one tavern: colonial Kingston, New Jersey supported "The Sign of the Mermaid" (Muser, 1998: 54); visitors to colonial Mill Creek, Delaware flocked to the Mermaid Tavern between 1718 and the late 186os (Palmer, 2009); officials relied upon Oistins' (Barbados) Mermaid Tavern as a spot to sign land deeds in January 1651 (Parker, 2011: 74); and Londoners supported a variety of mermaid-branded taverns between the 17th and the 19th centuries.

Mermaid branding went beyond signage, for British tavern keepers also regularly issued metal tokens emblazoned with mermaids which served not only as unofficial currency, but also as portable advertisements for their maritime hubs. Great Britain was overflowing with these small-but-efficient coins (and coinciding machines) from the 16th through the 19th centuries (Rogers, 1928: 61-97). One only has to glance at the British Museum's (London) collections to understand the ubiquity of mermaid tokens, as it holds fifty-four separate pieces. Despite their variety - with London, Kilkenny, Bath, Devizes, Yeovil, Reading, Oxford, Colchester, Wallingford, Gravesend, Almondbury, Kent, Windsor, Hertfordshire, Warwick, Sherborne, Galway, and Rye tavernkeepers commissioning coins for their establishments - the tokens retained similar imagery (Mermaid Results, 2020). Thomas Ballett's mid-17th Century London example (Figure 2) is representative of most early modern mermaid coins. One side of the token was often defined by the tavern owner and his mermaid branding. Here, a traditional mermaid - a comb in one hand and a mirror in the other, with flowing hair, a bare torso, and a fish tail - marks the side, with the issuer's name circling around her. The other side of the keepsake generally provided the tavern's location. In this case, Ballett's Mermaid Tavern was located "in Red Cross Street." Cheap, portable, and easily recognised, these small advertisements extended publicans' reach well beyond their taverns' confines.

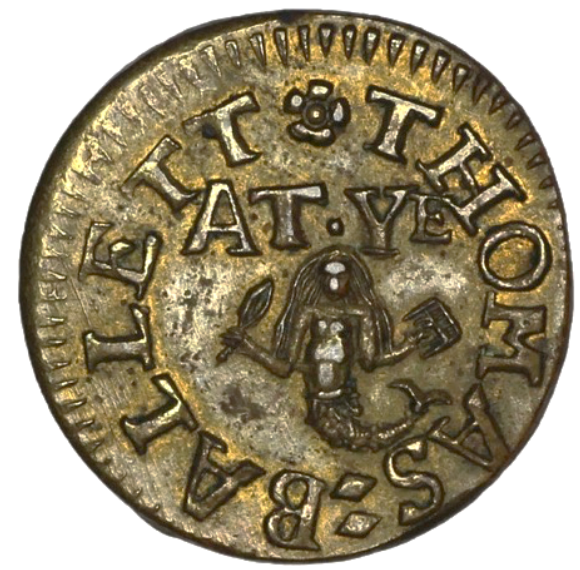

Figure 2 - Thomas Ballett's Mermaid Tavern Token Issued in London, England (Redcross Street, Cripplegate, 1649-1672). ${ }^{5}$

\footnotetext{
${ }^{5}$ https://www.britishmuseum.org/collection/object/C_T-3377 - accessed 21st August 2020.
} 
Ship owners employed similar tactics, as they emblazoned their bows with mermaid figureheads. As the historian Tony Lewis noted, "by the early 19th Century mermaids had emerged as one of the most common figurehead subjects, despite their traditional role as sirens who lured gullible seamen onto treacherous reefs" (1996: 838). Early modern mermaid figureheads mirrored tavern signs and coinage in their imagery and purpose. Mounted prominently on the ship's bow (and sometimes prow), these buxom wood figures, which could reach up to nine feet in length, reflected the crew's deeper beliefs, especially concerning superstition, a longing for female companionship, and exploration. Mermaid figureheads in particular were often the sole females "on board" the ship, and thus demanded more reverence than, say, a unicorn or eagle. In the case of Frederick, Prince of Wales' surviving barge, the mermaid figurehead is taken a step further with bright gold paint. Yet she retains many of the classical traits of a mermaid - bare breasts, a pearl necklace, and undulating serpentine tail (Figure 3). Though such a barge would have only seen duty on the River Thames as an escort for the royal family, the mermaid figurehead nonetheless represented larger maritime prominence.

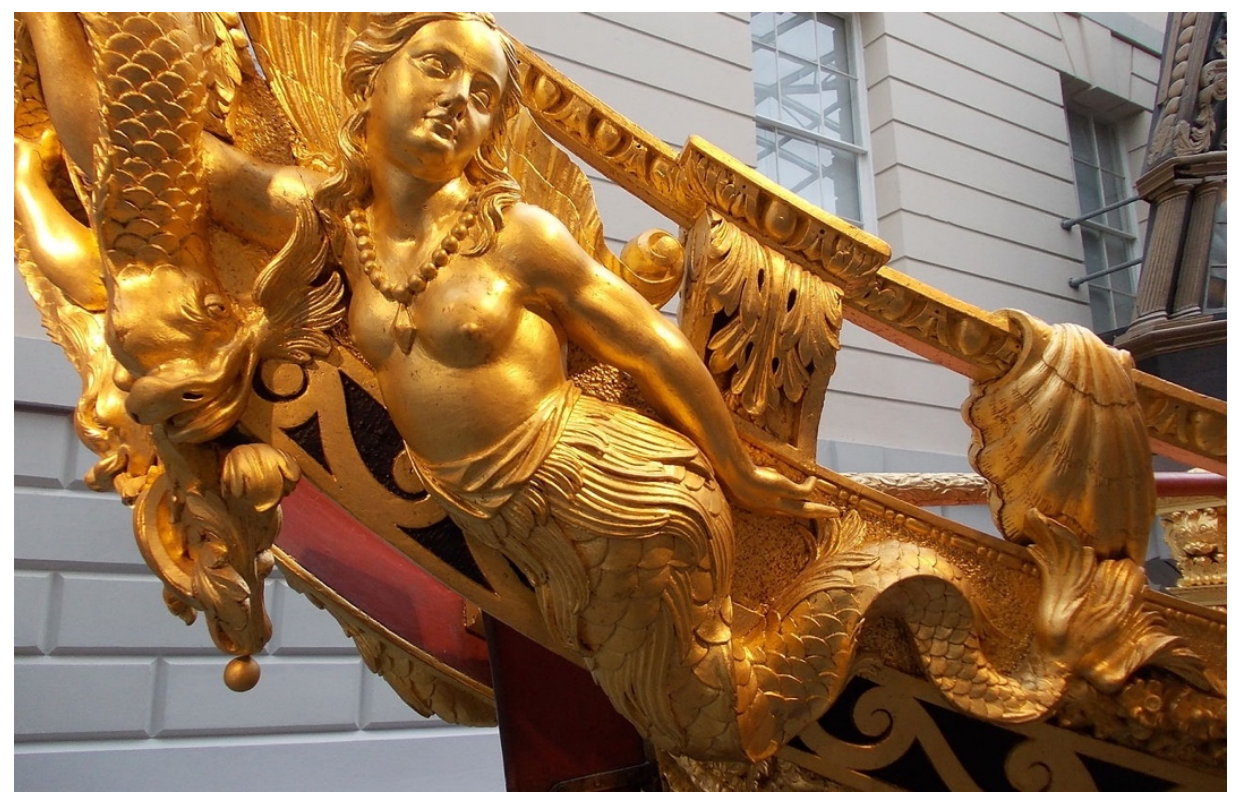

Figure 3 - Part of a Mermaid Figurehead of Prince Frederick's Barge (Carved by James Richards, 1731-32)." National Maritime Museum, Greenwich, UK. (Photograph by Chiswick Chap - Wiki Commons.)

Although mermaids became some of the most popular female figureheads in the AngloAmerican world by the early 19th Century, few examples survive. If a ship survived service it was generally dismantled, along with its figurehead. However, many ships wrecked. The April 14, 1838 issue of the Columbia Democrat (Bloomsburg, Pennsylvania) re-printed "A Pathetic Fish Story,” by J.H. Hewitt, which mocked the fictional sailor, Hiram Ceffin's, credulity regarding the existence of mermaids. Upon hearing splashes in the ocean and believing he had seen a real mermaid, Hiram plunged into the water, only to find "the figurehead of the brig 'Mermaid,' which was lost some time ago, off the island!" Exclaiming to his worried wife that it was "nothing but wood," Hiram put his "wooden sea-nymph" in 
the corner of their home (Unattributed, 1838: 4). The English painter, James Clarke Hook, similarly depicted three children wresting a mermaid figurehead from the rocky British coast in his 1883 painting, 'Catching a Mermaid' (Figure 4).

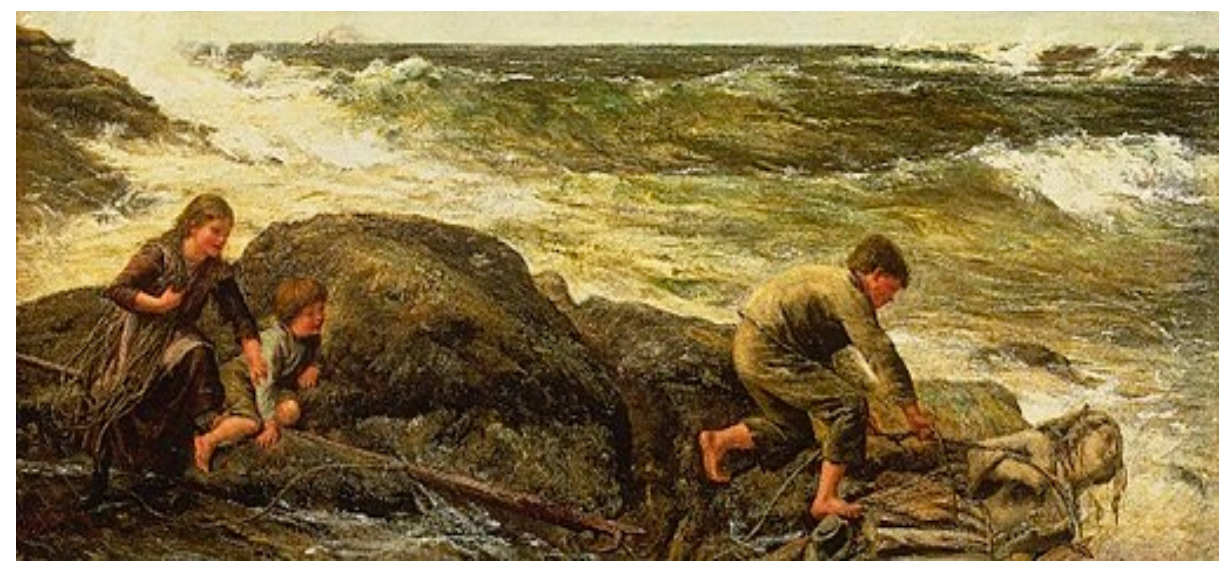

Figure 4 - (Detail from) James Clarke Hook 'Catching a Mermaid' (1883). (National Maritime Museum, Greenwich, UK.)

Early-to-mid-19th Century ship construction and financial records provide further insight into the regularity of mermaid figureheads. In 1851, the Mermaid was commissioned in Boston, surfeit with a "figurehead of a mermaid with a comb and spyglass [mirror] in hand," while a contemporary ship, the Siren, featured a mermaid "rising dramatically out of the ocean" (Knoblock, 2014: 309, 56). North-eastern American ship makers finished the Siren Queen in 1856 and commissioned a mermaid figurehead to be carved in Boston (Pinckney, 1940: 148). The British Royal Navy also contracted mermaid figureheads for siren-branded ships. Though in 1820 a proposal for a "full-length mermaid" figurehead was denied by Her Majesty's Navy for the Brig-sloop Siren, by 1840 a "mermaid bust" was approved for the same ship, which served for twenty-eight years (Pulvertaft, 2011: np).

In a clear connection to taverns and ships, sailors often tattooed their bodies with mermaid symbology. This is no small detail, as sailors were some of the only early modern AngloAmericans who touted tattoos (Newman, 1998: 61). And, like tavern signs and ships' figureheads, tattoos rarely "survived," and were instead buried with their owners. Nevertheless, records remain. For instance, newspapers often printed detailed physical descriptions of dead or runaway sailors which mentioned tattoos. In July 1811, a man washed up on the north-western shore of England "very much attired and ornamented like a sailor." The Lancaster Gazette explained that he was:

marked on the back of both hands, with anchors; and on the left hand, with the letters T.F. on the left breast were also depicted a mermaid, bird, sun, and something resembling the human face. On the right breast were a star, a fish, and the following lines, fairly inscribed:

My mind is fix'd I cannot range;

I like my choice too well to change (Unattributed, 1811: 1). 
Newspaper descriptions of sailors so "ornamented" continued well into the mid-19th Century. In April 1846, the Columbian Fountain (Washington D.C.) narrated the sad story of one sailor who died of "the Fatal Effects of Intemperance." In describing the "unknown white man," the newspaper explained, "the figure of a mermaid was on his left arm, and an anchor on the back of his right hand" (Unattributed, 1846: 3). One year later, the Sydney Morning Herald cautioned readers about "Thomas Finney, who arrived per ship Lady Harewood," and had recently lost his certificate of freedom. Beyond Finney's age, height, hair-colour, and trade, the editor also noted that he had a "mermaid in right arm [and] man and woman on left arm" (Unattributed, 1847: 1).

But newspaper notations are only the tip of the proverbial iceberg, as historians recently delved into the physicality - especially tattoos - of early modern Anglo-American mariners (Dye, 1989: 520-54; Newman, 1998: 59-82; Burg, 1994: 161-74; Gilje, 2016: 261). In 1989, Ira Dye used early 19th Century protection certificates and prisoner of war records to survey early American seafarers' tattoos in critical detail. Dye found that, between 1796 and 1803, 20.6 percent of seafarers recorded by the Philadelphia Seamen's Protection Certificate Applications had tattoos, $20.8 \%$ of which were "things of the sea." $82.3 \%$ of sailors' tattoos were on their arms, and $67.6 \%$ had one or two tattoos in total. And, while initials were the most popular tattoo, "mermaids, fish and ships" came in third most popular, with an average of $17.8 \%$ (these "things of the sea" were most popular in men over fifty years old). Though the prevalence of tattooing among sailors declined over the next fifteen years to around $4 \%$, the average was nonetheless far above the general population (Dye, 1989: 53336, 540).

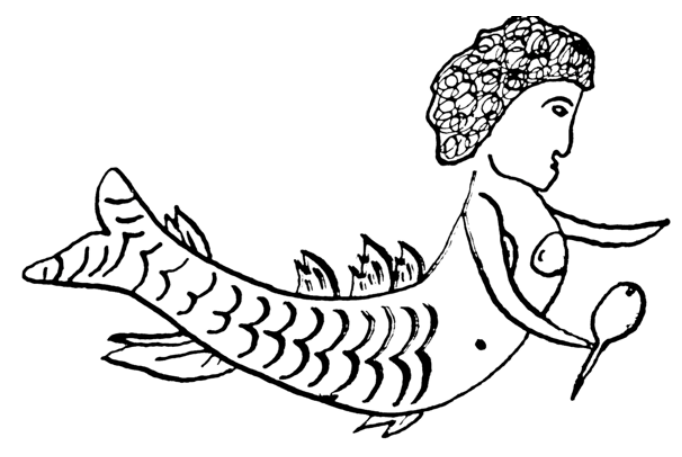

Figure 5 - 'A Mermaid Tattoo of 1808, from a Preserved Skin Specimen' (in Dye, 1989: 545).

Dye not only gained access to meticulous descriptions of mariners' tattoos, but also perfect restorations and, in some cases, literal skin fragments with the tattoo intact. Dye recreated an 1808 preserved skin fragment tattoo from Guy's Hospital (London) which represented a classical mermaid (Figure 5). Though the owner of this tattoo is lost to history, his preserved tattoo lives on, and provides us a brief-but-important glance into the maritime early modern Anglo-American maritime culture. These work-hardened men became vessels of oceanic symbolism; living representations of their shared maritime culture and ongoing attachment to one of the ultimate icons of sea-faring life: the mermaid. Sailors' mermaid tattoos transcended art, as they provided them instant connection points through which to identify other members of their larger imagined community. Upon entering a tavern or just walking the streets of a port city, sailors could instantly identify each other according to their tattooed bodies. Such cultural cues went beyond race, nationality, and 
language, allowing mariners an immediate point of connection on land or at sea, while also defining themselves as sailors to the rest of society. In the classic Robert Louis Stevenson novel, Treasure Island (published in 1883 but set in the mid-18th Century), a mysterious sea captain is accosted at a coastal England tavern, only to have a stroke on the tavern's stoop. When the local doctor rips off the captain's sleeve to bleed him, the narrator notes that his "great sinewy arm...was tattooed in several places" (Stevenson, 1884: 17).

Though a fictionalised account of maritime culture, Stevenson's Treasure Island nevertheless cut to the core of 19th Century Anglo-Americans' popular view of sailors, especially in terms of physicality. He explicitly noted the man's "great sinewy arm," thereby alluding to the strength required for the hard work at sea. In describing the man's various tattoos, furthermore, Stevenson clearly linked the life of the sailor with the self-expression of body ink: 'Here's luck,' 'A fair wind,' and 'Billy Bones his fancy,' were very neatly and clearly executed on the forearm; and up near the shoulder was a sketch of a gallows and a man hanging from it-done, as I thought, with great spirit" (Stevenson, 1884: 17). And, while no mermaid resided on the captain's body, Stevenson was sure to include two of them at the top of his imaginary map of the "Treasure Island" (Figure 6).

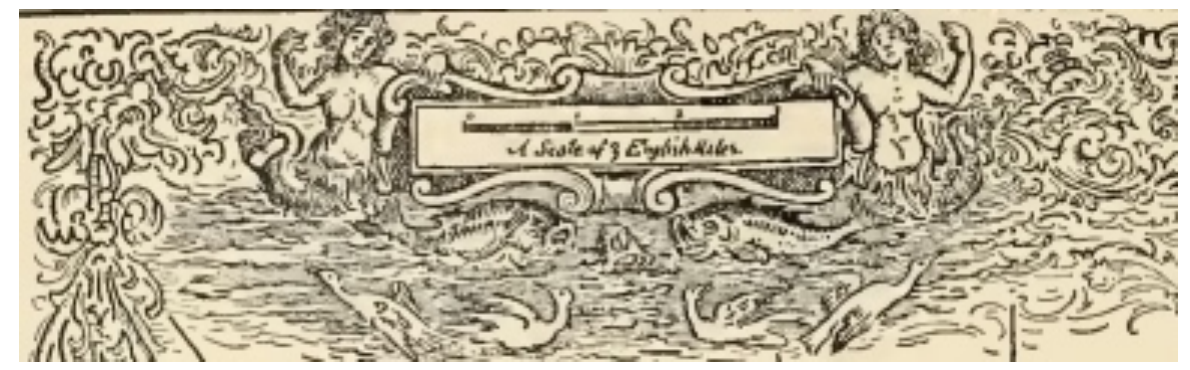

Figure 6 - Detail from Map of Treasure Island, Stevenson (1883).

Sailors harboured more than tattoos to project their shared maritime mermaid culture: songs were critical activities which linked sea life with land life and, in turn, created pockets of sociability among diverse mariners. Whether crowded into a tavern or labouring on the deck of a ship, sailors could join in ballads which encouraged bonhomie while also passing the time, helping sailors maintain a wariness of the sea, and encouraging connections to life beyond their current plight. It should come as no surprise that songs about mermaids were some of the most popular. The folk ballad, 'The Mermaid' (which dates to the mid-17th Century) began life as a somewhat dour ditty, as it depicted mermaids as dangerous sirens who brought sailors to their deaths. This makes sense, as until the early 18th Century, mariners associated mermaids with destruction and bad luck. However, as the song gained favour over the next century, performers surely latched on to the whimsical passages ("Last Easter day, in the morning fair; We was not far from land; Where we spied a mermaid on the rock; With comb and glass in hand") as much as the sad ones. However, the melancholy portions of the song retained importance, as they allowed sailors to share feelings of sorrow and fear "in company" of others who had at least a general understanding of their emotional plight (Childs, 1804: 148-50; Atkinson, 1998: 43940, 446).

Songs and ballads about mermaids often overlapped with sailors' tales of mermaid sightings and interactions. As historian Paul Gilje contended, "men of the sea prized their ability to tell tales, holding their audience spellbound and stretching the truth past the 
point of credibility" (Gilje, 2016: 81). What better "yarn" to captivate an audience than one about a mermaid? Because a full compendium of every early modern mermaid sighting is beyond this article's scope, a few examples must suffice. Christopher Columbus and Henry Hudson both claimed to see mermaids in the Atlantic Ocean, while Captain Richard Whitbourne sparked one of the most famous - and cited - interactions in 1610, when he reported a mermaid off the coast of Newfoundland. Here was a well-respected Englishman with a full, in-depth sighting! (Scribner, 2017: 507-38).

By the 18th Century, stories like Whitbourne's became commonplace in the maritime community. In 1716, Cotton Mather was convinced of merpeople's existence after three sailors - "honest and credible men" - claimed to have seen one while "coming in a boat from Milford to Brainford (which towns lie near one another on the south-shore in our colony of Connecticut)" (Mather, 1716). By 1739, a group of sailors told the Scots Magazine that they had survived on mermaid flesh in the East Indies (Benwell and Waugh, 1965: 106). After a trip to the South Pole between 1822 and 1824, finally, the English captain, James Waddell, related the story of a crewmember who saw a mermaid in the Bering Sea. Though Waddell was inclined not to believe the sailor, the captain could only remark that "he told me the story as I have related it, and in so clear and positive a manner, making oath as to the truth, that I concluded he must really have seen the animal he described, or that it must have been the effects of a disturbed imagination" (Waddell, 1825: 142-44). Captain Ahab of Herman Melville's novel, Moby Dick, set in the early-19th Century, leaned toward the "disturbed imagination" explanation when he laughed at a group of his sailors who believed they had seen a mermaid - Ahab explained that their "wonder" was no more than a group of seals (1892: 486).

As "imagination" coalesced with tales related "in so clear and positive a manner," sailors' yarns became popular entries in Western newspapers and periodicals. In 1832, American presses ran 'The Mermaid: An Eastern Tale,' which recounted “Captain Quizzle's" strange "adventure with a mermaid." Quizzle explained in great detail how he befriended a mermaid while stationed in the East Indies. Unfortunately, the captain grew too enamoured with this "water nymph," and was almost dragged to a watery grave. By the end of the story, Quizzle's audience exclaimed, "What a very extraordinary adventure, Captain Quizzle! And this is really a fact!" "A fact? No," Quizzle replied. "No?," the listener retorted, "What, is it fiction you have been telling us all this while?" "Every word of it," Quizzle concluded (Unattributed, 1832: 405). Here was the ultimate sailors' yarn, complete with a tantalising "hook" and the final reveal of trickery.

Graham's Magazine (Philadelphia) printed a similar story in its August 1843 edition. Titled 'A Fish Story,' the piece relayed the story of a mermaid encounter from "an ancient mariner, speaking words of solemn and deep import." Unlike Quizzle, this sailor actually went into the sea with the mermaid and toured her majestic home, only to decide to return to his ship. After being pulled back on board, he exclaimed, "They got me on board, where everything was as $I$ left it. They all said I must have got to sleep, and so rolled over board, but $I$ knew better" (Unattributed, 1843: 4). Though this yarn did not overtly admit fiction, it "sail[ed] along the borders of the factual and fanciful," which was, as Gilje contended, "the whole point" of a traditional yarn (2016: 165).

Sailors' construction skills extended into handicrafts, as they created various other mermaid-branded items at sea and on land. The sailor-turned-tavernkeeper, Stephen West, used mermaid-signed equipage to distinguish his London Town, Maryland tavern. In 1725, West offered patrons plates emblazoned with a blue mermaid floating on waves (Figure 7 ). 
West entertained many sailors at his seaport tavern, and thus used his mermaid plates much like other publicans used names, signs, and tokens (Luckenbach 2002). And West's plates were not unique in the early-modern Anglo-American world, as other ceramic makers also included mermaids in clear detail. Dutch delft tile makers were especially keen on producing such images (see, for example, Figure 8 ), ${ }^{6}$ which closely resemble West's local plates. One can imagine these $12 \times 12 \mathrm{~cm}$ tiles lining a tavern's interior walls, much like West's mermaid-branded plates on his tavern's tables.

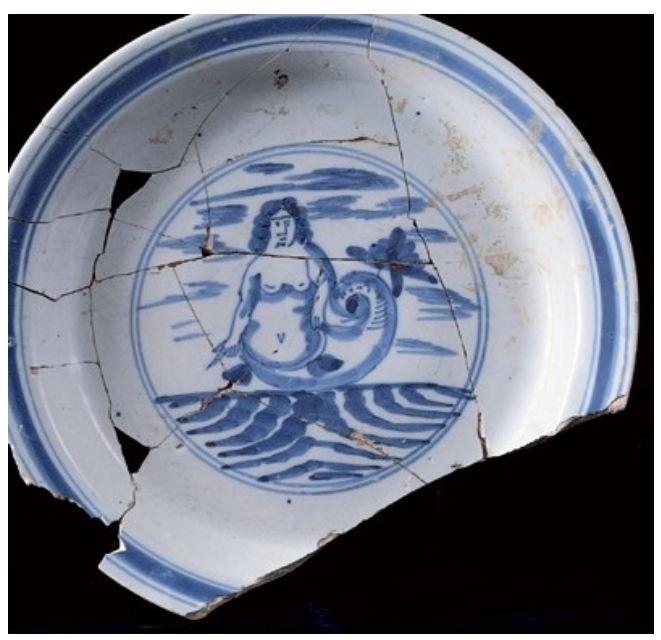

Figure 7 - 'Mermaid Plate (c. 1725)' courtesy of the Rumney/West Tavern, Historic London Town and Gardens, Edgewater, Maryland.

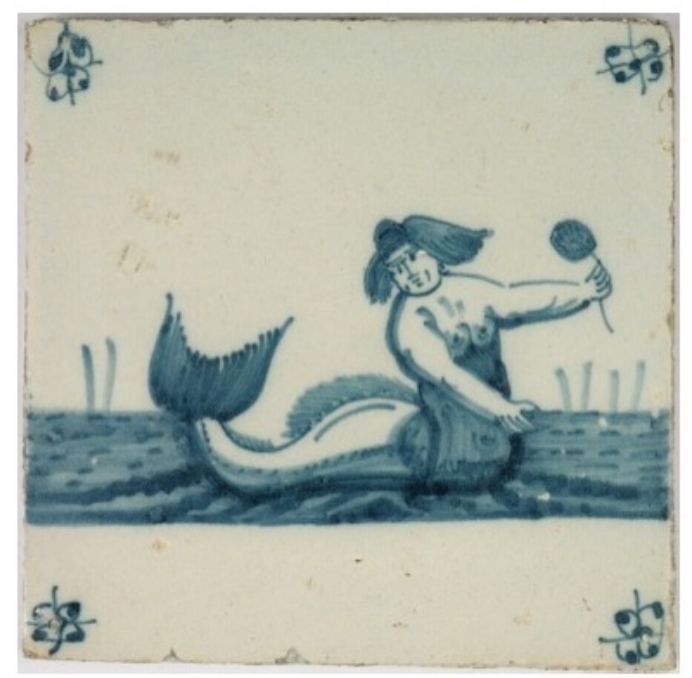

Figure 8 - 'Mermaid with Mirror-Delft, Netherlands, Eighteenth-Century Tile' (Archipel, nd: online).

\footnotetext{
${ }^{6}$ Also see other Dutch mermaid tile designs at Archipel (nd).
} 
Sailors also employed the time-honoured maritime tradition of scrimshaw to decorate powder horns. With so much down time at sea, sailors carved intricate designs into an animal horn with a needle or small knife. When craftsmen were pleased with the results, they rubbed the horn generously with grease, wax, or ash in order to make their carvings stand out against the horn's yellow hue (Durand, 2018). Sailors often depicted mermaids on their horns, many of which survive to this day. Recent auction records provide a clear survey of mermaid horn scrimshaw. In 2018, a late-18th Century horn sold at the Clarke Auction Gallery (Larchmont, New York) which featured a buxom mermaid (Figure 9), along with other maritime-associated symbols such as an eagle, cannon, and liberty cap (recall the whale tooth scrimshaw in the beginning of this article).

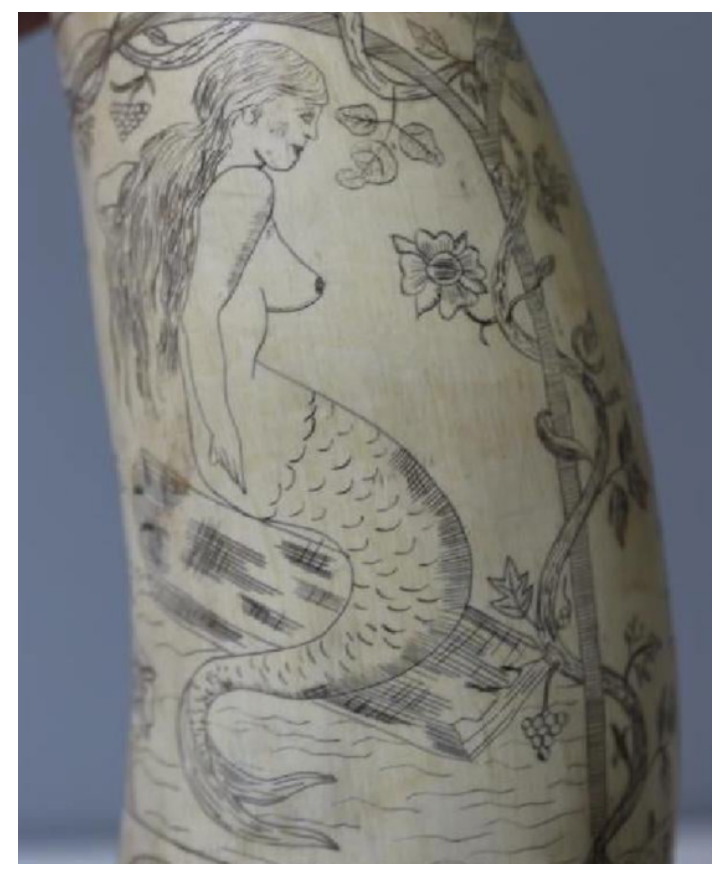

Image 9 - 'Buxom Mermaid Carved onto Eighteenth-Century Powder Horn' (Live Auctioneers website) ${ }^{7}$

Another example dates to 1805 and showcases similar maritime iconography. A mermaid defines one side of the horn (Figure 10), while the other side is covered with lady liberty holding a ship's anchor (Figure 11). As with tattoos, sailors' mermaid-branded powder horns would have immediately demonstrated their maritime ties.

\footnotetext{
${ }^{7}$ https://www.liveauctioneers.com/en-gb/item/64169734_engraved-and-scrimshawed-antiquepowder-horn - accessed 22nd August 2020.
} 


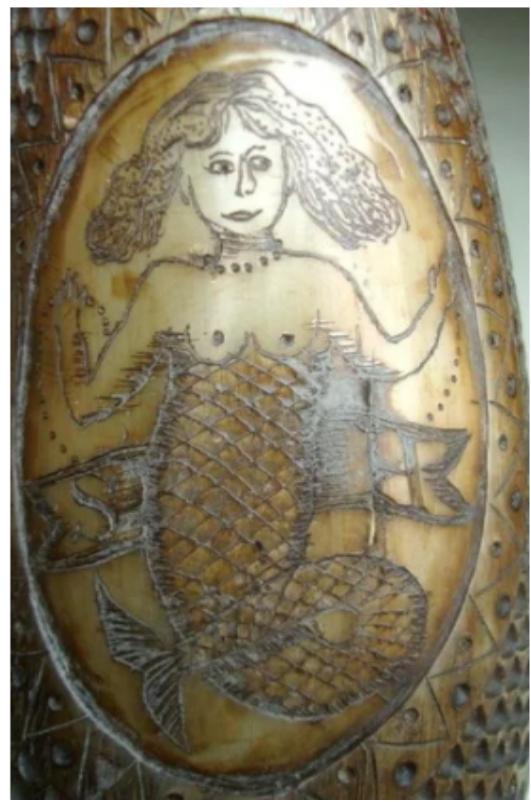

Figure 10 - Mermaid Carving on 1805 Powder Horn (Live Auctioneers website) ${ }^{8}$

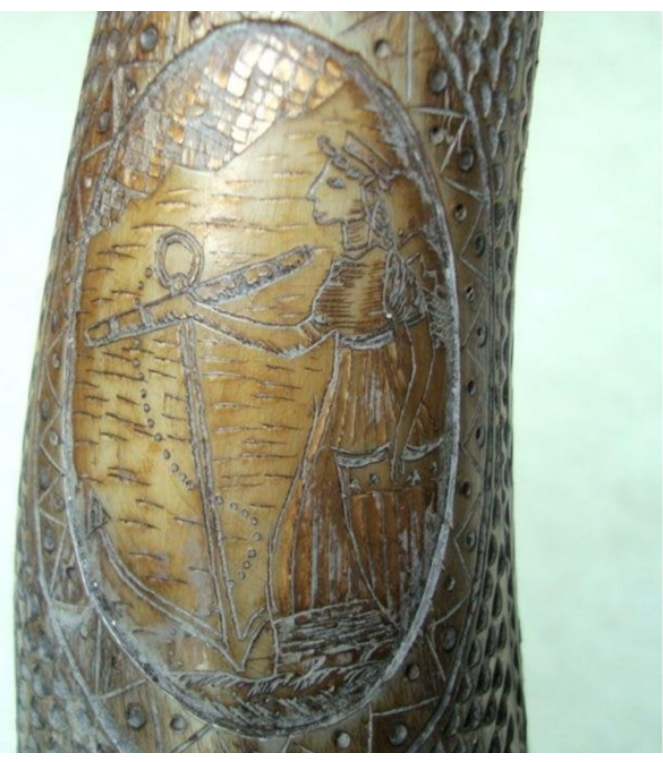

Figure 11 - Lady Liberty Carving on 1805 Powder Horn (Live Auctioneers website) ${ }^{9}$

\footnotetext{
${ }^{8}$ https://www.liveauctioneers.com/en-gb/item/16850782_scrimshaw-maritime-handcarved-hornpowder-flask - accessed 22nd August 2020.

${ }^{9}$ https://www.liveauctioneers.com/en-gb/item/16850782_scrimshaw-maritime-handcarved-hornpowder-flask - accessed 22d August 2020.
} 


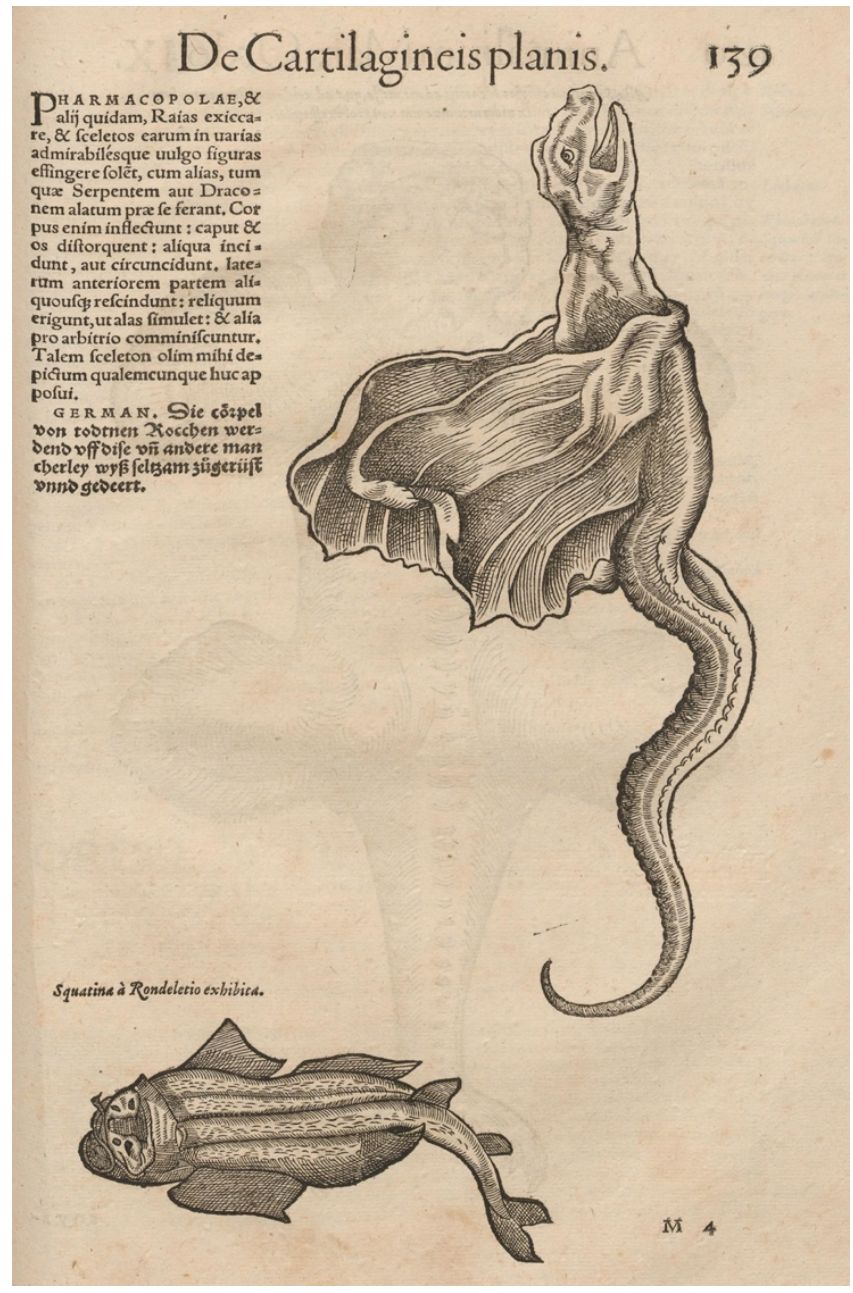

Figure 12 - 'Jenny Hanivers' (Gessner, 1560: 167).

Even more notably, sailors regularly purchased and crafted hand-made "mermaid specimens," which they then sold on land. They seem to have started the trend as early as the 16th Century with custom "Jenny Hanivers." In the case of these odd little "creatures," sailors contorted the skate fish's (ray family) cartilage and body with wire, then dried it out so that the common fish resembled a monstrous aquatic creature (Figue 12). Scholars wonder whether the name derives from the French phrase "jeunesse d'Anvers" (('youth of Antwerp'), which was then morphed into "Jenny Haniver" by British sailors (Gudger, 1934: 511-23; Dance, 1976: 43). No matter their origins, by the 18th Century Jenny Hanivers became popular tokens of maritime culture which sailors could exchange on land. In fact, London's Daily Post advertised the exhibition of one such creature on January 23, 1738:

To be Seen, next door to the Crown Tavern in Threadneedle Street, behind the Royal Exchange, at One Shilling each, the Surprising Fish or Maremaid, taken by eight Fishermen on Friday the $9^{\text {th }}$ of September last, at Topsham Bar, near 
Exeter, and has been shewn to several Gentlemen, and those of the Faculty, in the Cities of Exeter, Bath, and Bristol, who declare never to have seen the like, so remarkable is this Curiosity amongst the Wonders of Creation. This uncommon Species of Nature represents from the Collarbone down the Body what the Antients called a Maremaid, has a Wing to each Shoulder like those of a Cherubim mentioned in History, with regular Ribs, Breasts, Thighs, and Feet, the Joints thereto having their proper Motions, and to each Thigh a Fin; the Tail resembles a Dolphin's, which turns up to the Shoulders, the forepart of the Body very smooth, but the skin of the Back rough; the back part of the Head like a Lyon, has a large Mouth, sharp Teeth, two Eyes, Spout holes, Nostrils, and a thick Neck (Dance, 1976: 43).

In a canny blend of craftmanship and yarn-spinning, a sailor had tricked someone, not only into buying his little monstrosity, but wholly believing its authenticity. Even "the Faculty, in the Cities of Exeter, Bath, and Bristol" fell for his ruse (ibid).

Unfortunately for Anglo-American sailors, they were often on the other side of the trick. When Japan opened its ports to the Western world the 19th Century, Anglo-American mariners arrived in these distant lands expecting to find mermaids, and they did. Japanese ningyo (人形) mermaid specimens became popular purchases for merchants and sailors East Asia, and by the 19th Century, these strange little shrivelled up fakes steadily infiltrated British and American port cities. We still do not know whether Japanese craftsmen started making ningyo (a monkey and a fish combined with wires and plaster) to satiate Westerners' appetites for goods from East Asia, or if they had long been making them, but all that matters for this article's purposes is that mariners took the bait.

The most famous victim of ningyo fakery was the British captain, Samuel Edes, who exchanged a ship (which was not his) for a ningyo in 1822. Believing his mermaid was real, Capain Edes toured London with the creature before finally being discredited and disgraced. Ever the showman, P.T. Barnum purchased the same fake and toured America with it twenty years later (Bondeson, 1999: 38-47). By the end of the 19th Century, many Westerners referred to certain mermaid specimens as 'Feejee mermaids.' A Feejee mermaid was generally a small, shrivelled up specimen, and usually came from East Asia. Still today one can find 19th Century fake mermaids in private and public displays, including the famed "Enlightenment Gallery" at the British Museum (London). It is no coincidence that a sailor ignited 19th Century Westerners' obsession with mermaid specimens. AngloAmerican mariners had spent the last two centuries, if not more, realising a global maritime culture predicated upon diverse mermaid iconography. Thus, when Londoners crowded into the Turf Coffeehouse to view Captain Eades' mermaid specimen, they were only extending a long tradition of taverns and ships serving as key cultural spaces which connected land to sea, and vice versa (Bondeson, 1999: 38-9). 


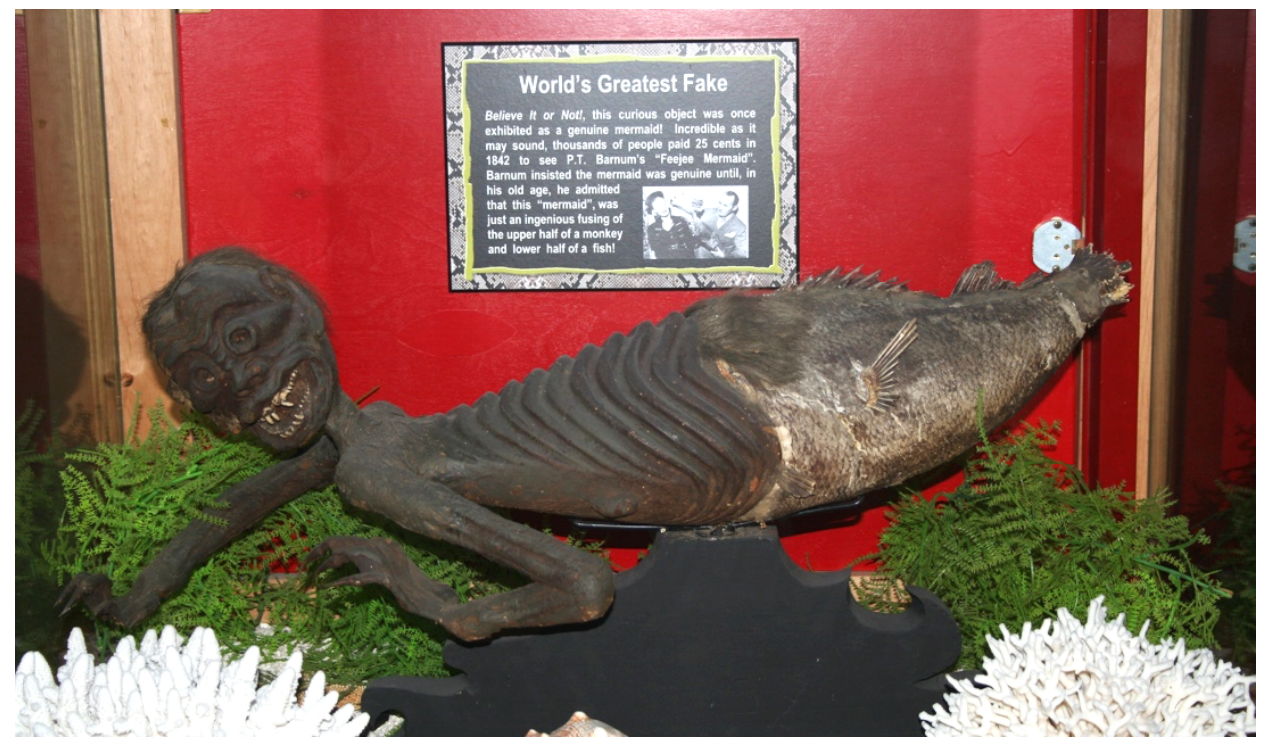

Figure 13 - 'Nineteenth-Century “Crawling” Feejee Mermaid (Ningyo)', Ripley's Believe It Or Not Museum in Seaside, Oregon, USA. (Photograph by Matt Crowley.)

As demonstrated by their associations with mermaid iconography, mariners' efforts at cultivating a shared maritime culture were inherently tied to muddled notions of liberty, masculinity, race, and sociability. Sailors' itinerant nature, furthermore, necessitated specific and well-understood spaces of interaction: taverns and ships. Combined with long-standing mermaid iconography - namely symbolism, objects, superstitions, stories, and songs - these spaces helped sailors to carve out their own networks within a cultural milieu which often relegated seafarers to the literal and figurative fringes of society. Ultimately, mermaid iconography provides a unifying lens through which to better understand early modern Anglo-American sailors' ever-changing interpretations of the world and their place in it. Mermaids were some of the most iconic symbols for mariners, because they understood these mutable creatures as reflections of their own sense of self. Like mermaids, sailors maintained dual identities between the land and the sea, myth and reality, which demanded nuanced-yet-capricious cultural cues. The siren song satiated these desires, allowing mariners easily recognisable points of correlation no matter where they journeyed.

\section{BIBLIOGRAPHY}

Anderson, B (2006) Imagined communities, London: Verso

Archipel International Maritime Gallery Online (nd) ' $18^{\text {th }}$ century Delft tiles with mermaid motifs': https://archipel-img.com/?s=mermaid - accessed 22nd August 2020

Atkinson, D (1998) 'The Child Ballads from England and Wales in the James Madison Carpenter Collection', Folk Music Journal v7 n4: 434-49 
Benwell G and Waugh A (1965) Sea enchantress: the tale of the mermaid and her kin, New York: The Citadel Press

Bondeson, J (1999) The Feejee mermaid and other essays in natural and unnatural history, Ithaca: Cornell University Press

Bolster, W (1997) Black Jacks: African American seamen in the age of sail, Cambridge: Harvard University Press

Brennan, T, Hancock, D and McDonald, M (eds) (2011) Public drinking in the early modern world: voices from the tavern, 1500-180o, volume 4, London: Pickering \& Chatto

Burg, BR (1993) 'Sailors and tattoos in the early American steam navy: evidence from the Diary of Philip C. Van Buskirk, 1884-1889', International Journal of Maritime History v6 nı: $161-74$

Carp, B (2007) Rebels rising: cities and the American Revolution, Oxford, UK: Oxford University Press

Childs, J (1804) The English and Scottish popular ballads, part four, Boston: Houghton, Mifflin and Company

Creighton, M and Norling, S (eds) (1996) Iron men, wooden women: gender and seafaring in the Atlantic world, 1700-1920, Baltimore: Johns Hopkins University Press

Cuming, H (1882), 'Mermaids (Read June 1, 1881)', Journal of the British Archaeological Association v38: 6o-64

Dance, S (1976) Animal fakes \& frauds, Charlottesville: University of Virginia Press

Durand, R (2018) 'The historical and personal importance of engraved powder horns', Stories: City Artifacts; Museum of the City of New York:

https://www.mcny.org/story/historical-and-personal-importance-engraved-powder-horns -accessed May 26, 2020

Drewal, H (ed) (2008) Sacred waters: arts for Mami Wata and other divinities in Africa and the diaspora, Bloomington: Indiana University Press

Dye, I (1989) 'The tattoos of early American seafarers, 1796-1818', Proceedings of the American Philosophical Society v133 n4: 520-54

Gessner, K (1560) Nomenclator aquatilium animantium, Zurich, archived online: https://www.biodiversitylibrary.org/item/99439\# - accessed 22nd August 2020

Gilje, P (2004) Liberty on the waterfront: American maritime culture in the age of revolution, Philadelphia: University of Pennsylvania Press

Gilje, P (2013) Free trade and sailors' rights in the war of 1812, Cambridge: Cambridge University Press 
Gilje, (2016) To swear like a sailor: maritime culture in America, 1750-1850, Cambridge: Cambridge University Press

Gillis, J (2004) Islands of the mind: how the human imagination created the Atlantic world, New York: Palgrave Macmillan

Goodman, A (1983), 'The extraordinary being: death and the mermaid in baroque literature', Journal of Popular Culture v17 n3: 32-48

Gudger, E.W (1934) 'Jenny Hanivers, dragons and basilisks in the old natural history books and in modern times', The Scientific Monthly v38 n6: 511-23

Hatfield, A (2004) Atlantic Virginia: intercolonial relations in the seventeenth century, Philadelphia: University of Pennsylvania Press

Hewitt, J.H. (1838) 'A pathetic fish story', Columbia Democrat 14th April: 4

Hutchinson, J (1758) 'For sale by the candle...The good ship MERMAID', The Public Advertiser 16th June: 3

Knoblock, G (2014) The American clipper ship, 1845-1920: a comprehensive history, with a listing of builders and their ships, Jefferson: McFarland \& Company, Inc.

Laurence, A (1527) The noble lyfe and natures of man of bestes, serpentys, fowles and fishes be most known, Antwerp: archived online at:

https://wellcomecollection.org/works/bcvxkj8w/items?canvas=162\&langCode=eng\&sierraI d=b11513615 - accessed 16th December 2020

Lemisch, J (1968) 'Jack Tar in the streets: merchant seamen in the politics of revolutionary America', William and Mary Quarterly v25 n3: 371-407

Lewis, T (1996) 'Her effigy in wood: figureheads with feminine subjects', The Magazine Antiques v150 n6: 834-41

Linebaugh, P and Rediker, M (200o) The many headed hydra: sailors, slaves, commoners, and the hidden history of the revolutionary Atlantic, London: Verso

Luckenbach A (2002) 'Ceramics from the Edward Rumney/Stephen West tavern, London Town, Maryland, Circa 1725' in Hunter R (ed) Ceramics in America, Milwaukee: Chipstone Foundation: 130-52

Mather, C (1716) 'Cotton Mather to the Royal Society, July 5, 1716' Cotton Mather Papers, Massachusetts Historical Society, Boston

Melville, H (1892/1851) Moby Dick, or the white whale, Boston: C.H. Simonds Co.

'Mermaid tokens search results', The British Museum Online: https://www.britishmuseum.org/collection/search?keyword=mermaid\&keyword=token _ accessed May 18, 2020

Muser, J (1998) Rocky Hill, Kingston and Griggstown, Charleston: Arcadia Publishing, 1998 
Newman, S (1998) 'Reading the bodies of early American seafarers', William and Mary Quarterly v55 n1: 59-82

O'Callaghan, M (2004) 'Tavern societies, the inns of court, and the culture of conviviality', in A. Smyth (ed) A pleasing sinne: drink and conviviality in $17^{\text {th }}$-century England, Cambridge: D.S. Brewer: $37-51$

Palmer, S (2009) 'The Mermaid Tavern', The Mill Creek Hundred History Blog: http://mchhistory.blogspot.com/2009/o8/mermaid-tavern.html - accessed August 11, 2020

Parker, M (2011) The sugar barons: family, corruption, empire, and war in the West Indies, New York: Walker and Company

Pinckney, P (1940) American figureheads and their carvers, New York: W.W. Norton

Pulvertaft, D (2011) Figureheads of the Royal Navy, Annapolis: Naval Institute Press

Rogers, K (1928) 'On some issuers of seventeenth-century London tokens', The Numismatic Chronicle and Journal of the Royal Numismatic Society v8 n29/30: 61-97

Schoeppner, M (2019) Moral contagion: black Atlantic sailors, citizenship, and diplomacy in antebellum America, Cambridge: Cambridge University Press

Scribner, V (2017) “Such monsters do exist in nature": mermaids, tritons, and the science of wonder in eighteenth-century Europe', Itinerario v41 n3: 507-538

Stevenson, R (1884) Treasure island, Boston: Roberts Brothers

Unattributed (1752) 'Custom House, Philadelphia, inward entries', Pennsylvania Gazette 23rd July: 2

Unattributed (1755) Untitled lineage item, Pennsylvania Gazette 5th June: 2

Unattributed (1760), 'Scotland, Edinburgh, April 26', Public Advertiser 3rd May: 2

Unattributed (1763) 'From Lloyd's Evening Post of Friday night', Jackson's Oxford Journal zoth April: 3

Unattributed (1768) 'Boston, December 1', Hartford Courant 5th December: 3

Unattributed (1787) 'Ship news', London Times 6th August: 4

Unattributed (1811) Untitled lineage item, Lancaster Gazette 6th July: 3

Unattributed (1832) 'The mermaid: an Eastern tale', The Monthly Traveller v3: 403-405

Unattributed (1843) 'From Graham's Magazine for August: A fish story', Sentinel and Democrat 23rd August: 4 
Scribner - Mermaid Iconography and early modern Anglo-American maritime culture

Unattributed (1846) 'Fatal effects of intemperance', Columbian Fountain 18th: 3

Unattributed (1847) 'CAUTION’, Sydney Morning Herald 16th April: 1

Waddell, J (1925) A voyage towards the South Pole, performed in the years 1822-24, London: Longman 